\title{
Investigating the effect of electronic government in realizing social justice in Iraq
}

\author{
Heidar Najm ${ }^{1, *}$, Ruhollah Tavallaee \\ Department of Information Technology Management, Shahid Beheshti University, Tehran, Iran \\ ${ }^{1}$ heydarnajm92@gmail.com* \\ * corresponding author
}

\begin{abstract}
ARTICLE INFO ABSTRACT
Article history

Received August 11, 2018

Revised September 6, 2018

Accepted September 29, 2018

The increasing use of information technology, communication tools and applied programming has led to the development and evolution of public policies, processes, and functions. Information and communication technology is entering not only the provision of citizen services, but also public utilities, improving accountability and transparency in government performance, and saving government costs and government management. Developing countries are moving toward e-government, but in order to succeed in deploying e-

Keywords

Social justice

E-government

Governmental management government, cultural and institutional considerations must be taken into consideration. This is a survey research and the statistical population includes experts in e-government in Iraq. Therefore, using Morgan's table, 196 experts have been selected. To collect data, questionnaires were used. Through the study it was found that in terms of the development of the rule of law, Iraq's Missan Oil Company is in a good condition, and 55 percent of the respondents believed that the expansion of the rule of law, the behavior based on the principles and rules and avoiding to impose personal interests are the results of the deployment of e-government. Furthermore, according to the results and considering that out of six existing sub-hypotheses, 5 sub-hypotheses were confirmed, the main hypothesis of the research which is based on the effect of e-government on social justice is confirmed.
\end{abstract}

This is an open access article under the CC-BY-SA license.

\section{Introduction}

At present, the most accountable form of government which satisfies people's expectations is the e-government. The goal of establishing e-government is providing people with better services, improving services for business, transparency, empowerment through information and creating efficient government [1]. Thus, many experts believe that today it is possible to overcome some of the human problems with the help of the technologies that mankind has gained at this time. Among these technological innovations is information technology. Governments hope that with the help of information technology, they will be able to overcome many of these problems and thus, can accelerate the development path [2].

Developing countries are moving toward developing e-government, but cultural and institutional considerations must be considered in order to succeed in deploying e-government [3]. The egovernment, as an applied area, essentially invites the users to face the challenges of the new Internet media and wants them relying on their initiatives and through using new systems, remove those challenges. If we want to set a point for the start of activities in this area, we can refer to "US National Performance Review" program which was initiated in 1993 and emphasizes the role of e-government in federal government services. Subsequently, led by the vice president, Mr. Al Gore, who was linked with Clinton's strong centralized focus on the developed economy, it was luminous and was totally 
based on the new Internet technology, with a reciprocal influence on policy making and technology to promote both of them [4].

The fact is that although the terms used for the electronic government are synonymous, their meanings are not just the same. There are two limited and open definitions. In general, the two words "government" and "statesmanship" are confusingly used in research. Also, there are ambiguities to separate or combine the two terms of the "electronic democracy" and "electronic government". What is common among all definitions is that electronic government involves a comprehensive strategic approach for state organization, rather than the stage by stage automation of the government. The electronic government can be theoretically described as a method of drawing the perspective which in practice, guides the definitions on the basis of some theories, or uses the current measures to achieve descriptive definitions [5].

Meanwhile, ICT has developed all the technologies and businesses as well as oil and gas industry [2]. Due to the complex conditions in the world, the Iraq National Oil Company (NIOC) which is in the process of updating information and communication technology in this industry, in large-scale requires the recognition and macro-planning for ICT applications in the upstream business, which requires the use of e-government in the realization of social justice in the public organizations. Thus, the social responsibility of the Iraq National Oil Company is based on the idea of going beyond the legal requirements of business activity and achieving a positive impact on the environment and stakeholders, including customers, people, host communities, employees, and all those affected by the company's activities. Recognizing the role of e-government in the development of social justice in the National Oil Company of Iraq is one of the applied results of the research project, and government officials and employees will be among the beneficiaries [6].

Today, technological development across the world implies the use of information and communication technology which has been introduced as a new type of compliance with the principles of the public sector. The increasing use of information and communication technology and applied programs has led to the development of the public policies, processes and functions. Information and communication technology not only serves citizens, but also is used to increase the productivity in public sectors, improve accountability and transparency in government performance, and save the costs of government and state management [5].

\section{Literature Review}

The society, in other words, is a set of people living together and having a variety of cultural, economic, and political relations with each other. A society has structures in all its simple and complex forms. The contemporary complex and industrial societies and the simple societies of the past have not just been formed through the gathering of individuals but each of them has its own social structure which distinguishes it from the other societies. The basic structure of a society consists of institutions [7].

Justice is one of the most important words in the history of human civilization and from the point of view of every human being with health ego, observing it has a great importance. So, no man (though he himself is crucial) denies it [8]. One of the tools to achieve justice is e-government. An electronic government often focuses on outsourcing, such as services provided to citizens.

The basis of social justice theories is that economic and social inequalities have an impact on its Judiciary organization, and any changes in the Judiciary organization, socio-economic relations and income distribution has direct effects on the society [6]. Undoubtedly, this deep and fundamental debate is controversial, has a wide scope, and deals with profound challenges in other epistemic areas such as ethics, the theories of personality, philosophy of law and epistemology.

In his later writings, John Rawls insists that it is possible to present a theory of justice which is purely political, without relying on a comprehensive philosophical or moral doctrine. According to him, his political conception of justice and its principles lacks a certain philosophical basis. He thinks that it is possible to create a framework for social and fair cooperation that would be accepted by all the scholars of comprehensive ethical, religious and philosophical doctrines and make it the base of the social structure of their society. This framework is outlined by the principles of justice that are not advocating the comprehensive philosophical or moral theory which he calls political liberalism. According to this political conception of justice, a desirable liberal society gives way to moral, 
religious, and philosophical pluralism and acts in a way that all people accept this fair framework which is not based on a specific comprehensive doctrine since the principles of political justice do not claim that they can answers specific moral and philosophical questions. Furthermore, these principles make comprehensive ethical and philosophical doctrines answer such questions so there is no rival who is sensitive to what people accept [9].

Social justice is one of the implications of the concept of justice, which means the "fair" allocation of resources in a society. In this sense, the law must achieve an acceptable level of genuine and formal justice and must guarantee the fair distribution of resources and opportunities. In modern state management, the principles of social justice are one of the aspects of a new paradigm in state governance and especially emphasize the role of state administrators in providing and delivering highquality services to citizens and groups [10].

With the increase of public confidence, the pessimism to the government decreases, the cost of mutual control for both the government and the nation decreases. It seems that this situation affects the government in all three areas of economic, political and cultural activity [11]. Trust plays an important role in maintaining the cohesion and solidity of social relations; this role becomes more prominent in the realm of the economy and has become a vital role for all actors, both individual and organizational, so that numerous studies, especially in the last decades of the previous century focused on the positive and direct correlation between the health of the economic system and social confidence [12].

\section{Method}

Since the focus of this research is on the number of experts and specialists in the field of electronic government in Iraq, the managing and planning organization of Iraq was selected as the statistical population (expert population) and using the Morgan table, 196 experts were selected as samples. Since the present research is a field research, the most common tool to collect information in this type of research is questionnaire. Therefore, the data gathering tool in this research is a questionnaire, which is included in the research appendix.

There are seven independent variables in the questionnaire: (1) Increase in governmental transparency in electronic government, (2) Development of rule of law in electronic government, (3) The necessity of answering in electronic government, (4) Attention to justice and fairness, (5) Increase in participation, (6) Effectiveness and efficiency, and (7) Attention to the necessity of social consensus. In this questionnaire, four questions are personal questions. The first question is the amount of work experience in the organization and the second and third questions are age and gender, respectively, and the last question in this section is the level of education. The dependent variable in this research is social justice, which in the questionnaire indirectly and directly related to the other dependent parameters are evaluated.

Table 1. Scale and Measurement Coefficient of the Questionnaire.

\begin{tabular}{cc}
\hline Measurement Scale & Measurement Coefficient \\
\hline very high & 9 \\
\hline high & 7 \\
\hline moderate & 5 \\
\hline low & 3 \\
\hline very low & 1 \\
\hline
\end{tabular}

In the questionnaire, opinions and tendencies of the responders about the subject are asked. According to the Likert scale, the responses are ranked from very high to very low. The scale and measurement of the questionnaire shown in Table 1. Therefore, the responder has no limits to answer and is not limited in predetermined categories. In this questionnaire, the severity of the effect of each factor was measured using arithmetic mean, mean of each indicator (1) and weight of each indicator (2). In these two formulas, $\mathrm{A}_{\mathrm{j}}, \mathrm{r}_{\mathrm{i}}, \mathrm{n}$ and $\mathrm{W}_{\mathrm{j}}$ are arithmetic mean of indicator $\mathrm{j}$, scores obtained for each indicator by the person I, sample number and weight of indicator $\mathrm{j}$, respectively. 


$$
\begin{aligned}
A_{j} & =\frac{\sum r_{i}}{n} \quad \mathrm{i}=1,2,3, \ldots ., 56 \quad \mathrm{j}=1,2,3, \ldots \ldots, 60 \\
W_{j} & =\frac{A_{j}}{\sum A_{j}} \mathrm{j}=1,2,3, \ldots . ., 60
\end{aligned}
$$

To confirm the research hypotheses, it is necessary to analyze the collected data based on the statistical tests. In this regard, two parts of statistics, descriptive statistics and statistical inference are used. Descriptive statistics including frequency distribution tables, central tendency and dispersion Index (mean, standard deviation, skewness and elongation) and bar charts are used to describe the data. Inferential statistics test, including t-test to compare two independent groups, $\mathrm{f}$ test (variance analysis test) to compare more than two groups, Pearson correlation coefficient to study simple relationships between research variables and multiple regression coefficients to analyze the effect of the variables. The $t$ test method examines the hypothesis related to mean of statistical population.

Since our hypotheses examine the degree of correlation between the two variables, correlation coefficient is needed. As in the definition of correlation coefficient, the intensity of the dependence of the two variables is called correlation coefficient, which is a number between -1 and 1 . The closer the number is to one, the greater the correlation is. In the science of statistics, there are many types of correlation coefficients, each of which measure the correlation between the two variables according to the type of data and the variable conditions. Therefore, when using these methods, the type of variables used in the research should be paid special attention. Since both variables are ratio-interval and both variables are quantitative in the research, the Pearson correlation coefficient based on the two-variable variance and their standard deviation, which has a high power among other types of correlation coefficients, is used. The total statistical analysis is done in the SPSS software.

\section{Result and Discussion}

\subsection{Descriptive Statistics}

The gender distribution of respondents is in a way that $18 \%$ are female and $82 \%$ are male. Furthermore, the age distribution of respondents can be seen in Table 2.

Table 2. The age distribution of respondents

\begin{tabular}{cccc}
\hline Age & Frequency & Relative frequency & Cumulative relative frequency \\
\hline $21-30$ & 42 & 21 & 21 \\
\hline $30-4$ & 36 & 18 & 39 \\
\hline $40-50$ & 44 & 22 & 61 \\
\hline $50-60$ & 36 & 18 & 79 \\
\hline$>60$ & 42 & 21 & 100 \\
\hline Total & 200 & 100 &
\end{tabular}

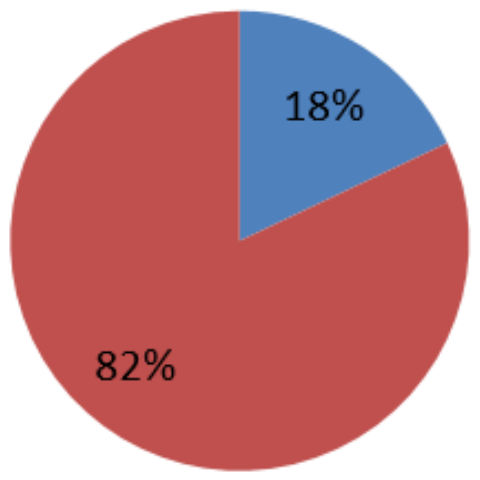

Male

Female

Fig. 1.Frequency distribution of respondents' gender 

Vol. 2, No. 2, December 2018, pp. 39-46

Table 3. Scoring and Description of the Used Questionnaire Results

\begin{tabular}{ccccccc}
\hline & $\begin{array}{c}\text { Number of } \\
\text { questions }\end{array}$ & $\begin{array}{c}\text { Absolutely } \\
\text { disagree }\end{array}$ & Disagree & $\begin{array}{c}\text { Have no } \\
\text { idea }\end{array}$ & agree & $\begin{array}{c}\text { Absolutely } \\
\text { agree }\end{array}$ \\
\hline $\begin{array}{c}\text { Increase } \\
\text { transparency }\end{array}$ & 4 & $4-6$ & $10-7$ & $14-11$ & $18-15$ & $20-19$ \\
\hline $\begin{array}{c}\text { Development of } \\
\text { rule of law }\end{array}$ & 3 & $5-3$ & $8-5$ & $11-8$ & $14-11$ & $15-14$ \\
\hline $\begin{array}{c}\text { The need for } \\
\text { accountability }\end{array}$ & 4 & $4-6$ & $10-7$ & $14-11$ & $18-15$ & $20-19$ \\
\hline $\begin{array}{c}\text { Attention to } \\
\text { justice and } \\
\text { fairness }\end{array}$ & 2 & $3-2$ & $5-4$ & $7-6$ & $9-8$ & 10 \\
\hline $\begin{array}{c}\text { Increase } \\
\text { participation }\end{array}$ & 6 & $9-6$ & $15-10$ & $21-16$ & $27-21$ & $30-28$ \\
\hline $\begin{array}{c}\text { Attention to the } \\
\text { need for } \text { social } \\
\text { consensus }\end{array}$ & 3 & $5-3$ & $8-5$ & $11-8$ & $14-11$ & $15-14$ \\
\hline
\end{tabular}

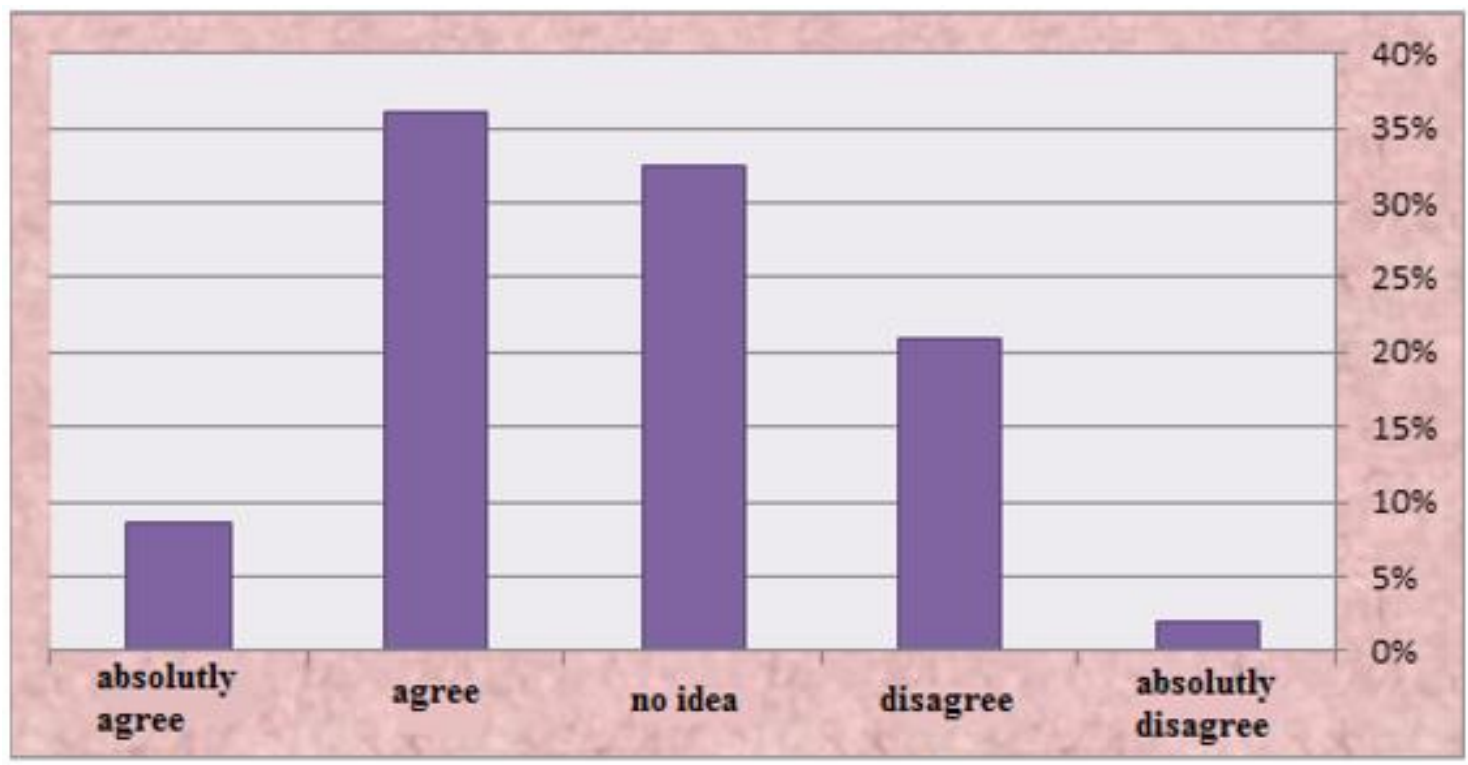

Fig. 2.Frequency distribution of increased transparency.

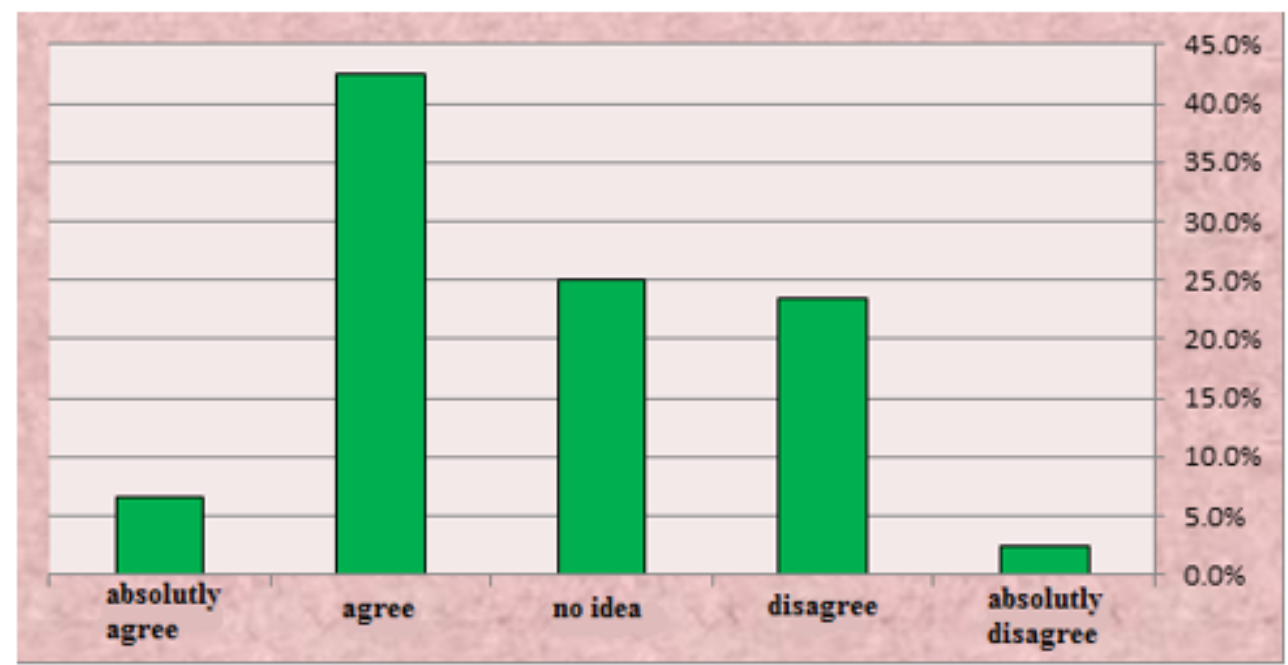

Fig. 3. Frequency distribution of the need for accountability. 


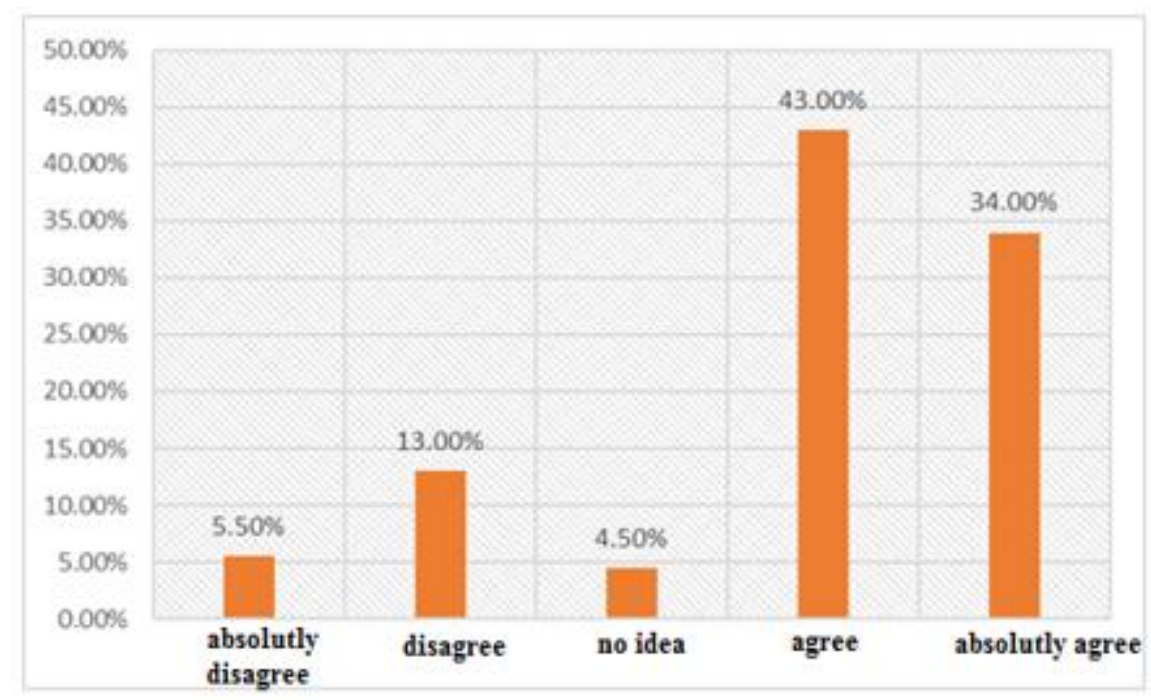

Fig. 4. Distribution frequency of attention increasing participation.

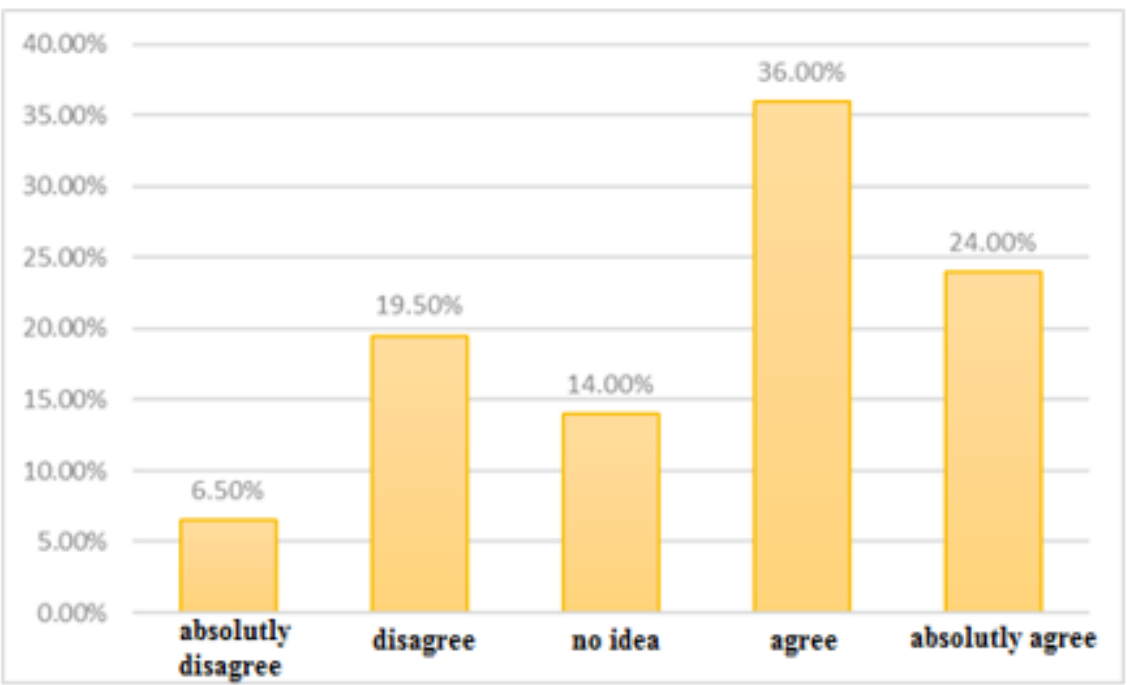

Fig. 5.Frequency distribution of variable considering the need for social consensus.

\subsection{Inferential Statistic}

The research variables were analyzed in the descriptive statistics section with the actual scores given. However, in order to ensure that the data are normal and the absence of any irregularity in the accuracy of the statistical tests, these variables were normalized using standard $Z$ score, and then we performed statistical tests. The formula of $\mathrm{Z}$ score is as follows:

$$
Z=\frac{X-\text { Mean }}{S . d}
$$

$\mathrm{X}$ is the responder's score, Mean is the mean of the variables and S.d is the standard deviation of the variable. Using the above equation, all the research variables were normalized so they have a mean of 0 and standard deviation of 1 , and replacing this change in the data, we can use parametric methods, ensuring the normal distribution of the data.

To determine the method of testing the hypothesis, first, it is necessary to be sure about the distribution of the variables of the research since this test determines which solidarity model has more similarity with our data. 
Table 4.

The Results of Descriptive Score

\begin{tabular}{cccc}
\hline & \multicolumn{2}{c}{ Inferential statistics } & The average \\
\hline The name of the variable & The number & $3 / 28$ & $1 / 439$ \\
\hline $\begin{array}{c}\text { The increase of } \\
\text { transparency }\end{array}$ & 200 & $3 / 37$ & $1 / 422$ \\
\hline Development of rule of law & 200 & $2 / 845$ & $1 / 425$ \\
\hline The need for accountability & 200 & $3 / 625$ & $1 / 392$ \\
\hline $\begin{array}{c}\text { Attention to justice and } \\
\text { fairness }\end{array}$ & 200 & $3 / 87$ & $1 / 397$ \\
\hline Increase participation & 200 & $3 / 515$ & $1 / 384$ \\
\hline $\begin{array}{c}\text { Attention to the need for } \\
\text { social consensus }\end{array}$ & 200 & &
\end{tabular}

Table 5.

Single Sample T-Test Results

\begin{tabular}{|c|c|c|c|c|c|c|}
\hline \multicolumn{7}{|c|}{ Variables single sample t-test results } \\
\hline \multirow{3}{*}{$\begin{array}{c}\text { The variable } \\
\text { name }\end{array}$} & \multicolumn{6}{|c|}{ The assumed average of society= 3} \\
\hline & \multirow{2}{*}{$\begin{array}{c}\text { The t } \\
\text { statistics }\end{array}$} & \multirow{2}{*}{$\begin{array}{l}\text { Degrees of } \\
\text { freedom }\end{array}$} & \multirow{2}{*}{$\begin{array}{c}p \text {-value } \\
\text { (bilateral) }\end{array}$} & \multirow{2}{*}{$\begin{array}{c}\text { difference in } \\
\text { averages }\end{array}$} & \multicolumn{2}{|c|}{$\begin{array}{c}\text { The confidence distance } \\
95 \% \text { average }\end{array}$} \\
\hline & & & & & lower limit & upper limit \\
\hline $\begin{array}{l}\text { The increase of } \\
\text { transparency }\end{array}$ & $2 / 751$ & 199 & $0 / 026$ & $0 / 28$ & $3 / 080$ & $3 / 479$ \\
\hline $\begin{array}{l}\text { Development } \\
\text { of rule of law }\end{array}$ & $3 / 679$ & 199 & $0 / 000$ & $0 / 37$ & $3 / 173$ & $3 / 567$ \\
\hline $\begin{array}{l}\text { The need for } \\
\text { accountability }\end{array}$ & $-1 / 538$ & 199 & $0 / 237$ & $-0 / 155$ & $2 / 647$ & $3 / 042$ \\
\hline $\begin{array}{l}\text { Attention to } \\
\text { justice and } \\
\text { fairness }\end{array}$ & $6 / 349$ & 199 & $0 / 000$ & $0 / 625$ & $3 / 432$ & $3 / 818$ \\
\hline $\begin{array}{c}\text { Increase } \\
\text { participation }\end{array}$ & $8 / 807$ & 199 & $0 / 000$ & $0 / 870$ & $3 / 676$ & $4 / 063$ \\
\hline $\begin{array}{l}\text { Attention to } \\
\text { the need for } \\
\text { social } \\
\text { consensus }\end{array}$ & $5 / 262$ & 199 & $0 / 000$ & $0 / 515$ & $3 / 323$ & $3 / 707$ \\
\hline
\end{tabular}

As we can see, in all variables except for the need for accountability variable, the value of the $t$ statistic is higher than 96/1 and the error level is smaller than 0.05 and the lower limit of the obtained values is also higher than 3 . Therefore, with all the reasons, the effect of e-government implementation on these variables is accepted.

\section{Conclusion}

The research findings highlighted the fact that only 45 percent of respondents were positive about increasing transparency resulting from the launch of e-government at the Missan Oil Company, which is indicative of the fact that e-government efficiency is well-suited to many operational and managerial levels It has not been described and there is a strong inertia from the staff and managers. Iraqi Missan Oil Company should improve this procedure and plan to reduce the negative attitudes of its employees along with the maintenance of procedures and working principles.

In relation to the development of the rule of law, the oil company Missan Iraq is in a good position. $55 \%$ of respondents view the rise of rule of law and the rule of law-based approach and avoiding personal loopholes as a result of the deployment of e-government. Regarding the need for accountability, the existing practices are not so interesting and employees do not distinguish between the traditional system and the e-government system. More than half of the studied population is not responding to the e-government's effectiveness.

Regarding the development of justice and fairness in e-government, we must say that this variable is much stronger than previous variables. Agreeing 64.5 percent of respondents with this topic is very interesting. The increase in the participation rate is above the level of justice and fairness, and with 
$80 \%$ of respondents' agreement, it can be said that the full glory is about the effectiveness of egovernment in the development of social justice.

The first hypothesis of the research based on the significant effect of "e-government" on "increasing the transparency" is confirmed to the t- statistic certificate with a value of 751.2 in a singlesample t-test with $95 \%$ confidence. As a result, the first hypothesis of the research is confirmed. The second hypothesis of the research is based on the significant effect of e-government on the "development of the rule of law" to the t- statistic certificate with a value of 679/3 in a single-sample t test with $95 \%$ confidence. As a result, the second sub-hypothesis of the research is confirmed. The third hypothesis of the research is that the "e-government" has a meaningful effect on the "the need of accountability" with the t-statistic of 1.385 in the one-sample t-test, which has no effectiveness. Because the mean confidence interval contains also 3, as a result, this hypothesis is not statistically significant and the third hypothesis of the research is rejected.

The fourth hypothesis of the research is based on the significant effect of e-government on "paying attention to justice and fairness" to the t-statistic certificate with a value of 349.6 in a single sample $t$ test with $95 \%$ confidence. As a result, the fourth sub-hypothesis of the research is confirmed. The fifth hypothesis of the research is based on the significant effect of e-government on the "increase in participation" to the t-test certificate with a value of 8.807 in a single-sample t test with $95 \%$ confidence. As a result, the fifth sub-hypothesis of the research is confirmed. The fifth hypothesis of the research is based on the significant effect of "e-government" on "the importance of social consensus" to the $t$ statistic certificate with a value of 5.262 in a single sample $t$ test with $95 \%$ confidence. As a result, the fifth sub-hypothesis of the research is confirmed. The main hypothesis of the research on the effectiveness of e-government in social justice, according to the confirmation of the 5 sub-hypotheses of the six existing sub-hypotheses, is confirmed.

\section{References}

[1] J. C. Bertot, P. T. Jaeger, and J. M. Grimes, "Using ICTs to create a culture of transparency: E-government and social media as openness and anti-corruption tools for societies," Gov. Inf. Q., vol. 27, no. 3, pp. 264 $271,2010$.

[2] M. R. bin Abdul Karim and N. M. Khalid, E-government in Malaysia: Improving responsiveness and capacity to serve. Pelanduk Publications, 2003.

[3] V. Ndou, "E-Government for developing countries: opportunities and challenges," Electron. J. Inf. Syst. Dev. Ctries., vol. 18, no. 1, pp. 1-24, 2004.

[4] Å. Grönlund, "State of the art in e-Gov research-a survey," in International Conference on Electronic Government, 2004, pp. 178-185.

[5] M. Hatam, "Key factors for success in implementing e-government in Iraq," Tarbiat Modares University, 2011.

[6] H. Kyoumars, A. Hooshmand, M. M. Varaz, V. baigi Sivan, and V. Sasan, "Analyzing the Social Justice in Spatial Structure of Sanandaj City," Armanshahr, vol. 4, no. 7, pp. 103-112, 2012.

[7] J. Rawls, The basic structure as subject. Dordrecht: Springer, 1978.

[8] L. L. Tung and O. Rieck, "Adoption of electronic government services among business organizations in Singapore," J. Strateg. Inf. Syst., vol. 14, no. 4, pp. 417-440, 2005.

[9] E. Kirchner and J. Sperling, EU security governance. Manchester: Manchester University Press, 2018.

[10]M. Moghimi and M. Alaei Ardakani, "Measuring good goverance factors and e-government role in enhancing it,” Q. J. Inf. Technol. Manag., vol. 3, no. 8, pp. 171-188, 2011.

[11]H. D., A. McGrew, D. Goldblatt, and P. J., "Global Transformations: Politics, Economics and Culture," in Politics at the Edge, C. Pierson and S. Tormey, Eds. London: Palgrave Macmillan, 2000, pp. 14-28.

[12]S. Szreter and M. Woolcock, "Health by association? Social capital, social theory, and the political economy of public health,” Int. J. Epidemiol., vol. 33, no. 4, pp. 650-667, 2004. 